\title{
Paleoearthquake evidence in Tenerife (Canary Islands) and possible seismotectonic sources
}

\author{
L.I. Gonzalez de Vallejo ${ }^{1}$, R. Capote ${ }^{1}$, L. Cabrera ${ }^{2}$, J.M. Insua ${ }^{1}$ and J. Acosta ${ }^{3}$ \\ ${ }^{1}$ Dpto. de Geodinamica, Universidad Complutense, 28040 Madrid, Spain. (vallejo@geo.ucm.es) \\ ${ }^{2}$ Laboratorio COAC, 38509 Guimar, Tenerife, Spain \\ ${ }^{3}$ Instituto Español de Oceanografia, C/ Corazón de María 8, 28002 Madrid, Spain
}

Key words: Canary Islands, Paleoliquefaction, Paleosismicity, Seismites, Seismotectonic, Tenerife

\begin{abstract}
A series of clastic dikes and tubular vents were identified in southern Tenerife (Canary Islands). These features are the result of seismic liquefaction of a Holocene sand deposit, as the consequence of a high intensity paleoearthquake. The peak ground acceleration (pga) and magnitude of the paleoearthquake generating these lique-

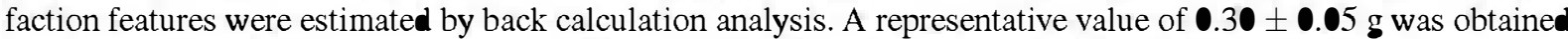
for the pga. From this, an earthquake intensity of $\mathrm{IX}$ was estimated for the liquefaction site. Magnitude bound methods and energy based approaches were used to determine the magnitude of the paleoearthquake, providing a moment magnitude $\mathbf{M}=6.8$. The zone in which the liquefaction structures are found has undergone tectonic uplift and is affected by two faults. One of these faults was responsible for displacing Holocene materials. Dating of the uplifted sand formation indicates an age of $1 \mathbf{0 , 0 8 1} \pm 933$ years, the liquefaction features ranging from this age to 3490473 years BP. This paleoearthquake was of much greater magnitude than those known historically. Faults with neotectonic activity are significant features that should be borne in mind when assessing the seismic hazards of the Canary Islands, presently considered as low and mainly of volcanic origin.
\end{abstract}

\section{Introduction and regional seismicity}

Several structures atributed to liquefaction phenomena of seismic origin have been identified in exposed sand deposits near El Médano, on the south coast of Tenerife, Canary Islands (Figure 1). These findings prompted subsequent tectonic investigations including the geotechmical characterization of soils, geochronological analysis, and the analysis of geophysical, seismicity, and neotectonic data which we report here. In these investigations, we were able to characterize a Holocene sand formation and analyze the liquefaction structures. Possible formation mechanisms and the origin and age of these structures were evaluated. In the same area, we identified two faults that affected the Holocene deposits. Estimates were made of the acceleration and magnitude of the paleoearthquake that produced these structures, and possible seismic sources were characterized
Based on earthquake information, the Canary Islands have been generally thought to experience low to very low seismicity, with earthquakes always associated with volcanic activity. During the historical period (Figure 2A), which starts in the XIV century with the first references to volcanic eruptions, the most intense earthquakes on the archipelago took place in Yaiza (Lanzarote) in 1730 (intensity X), in Fuencaliente and Cumbrevieja (La Palma) in 1677 and 1920, respectively (both VII), in Ingenio (Gran Canaria) in 1913 (VII), and in Fuerteventura in 1915 and 1917 (both VII). On the island of Tenerife, the maximum intensity recorded was VI for the earthquakes on 1910/03/15 in Icod, 1909/01/4 in Puerto de la Cruz, 1909/09/23 in La Orotava, 1909/11/21 in Vilaflor and 1937/06/21 in Garachico. In this historic record, six earthquakes of intensity VI were registered on Tenerife, all in the 20th century and mostly affecting the north side of the island or its capital city Santa Cruz. 


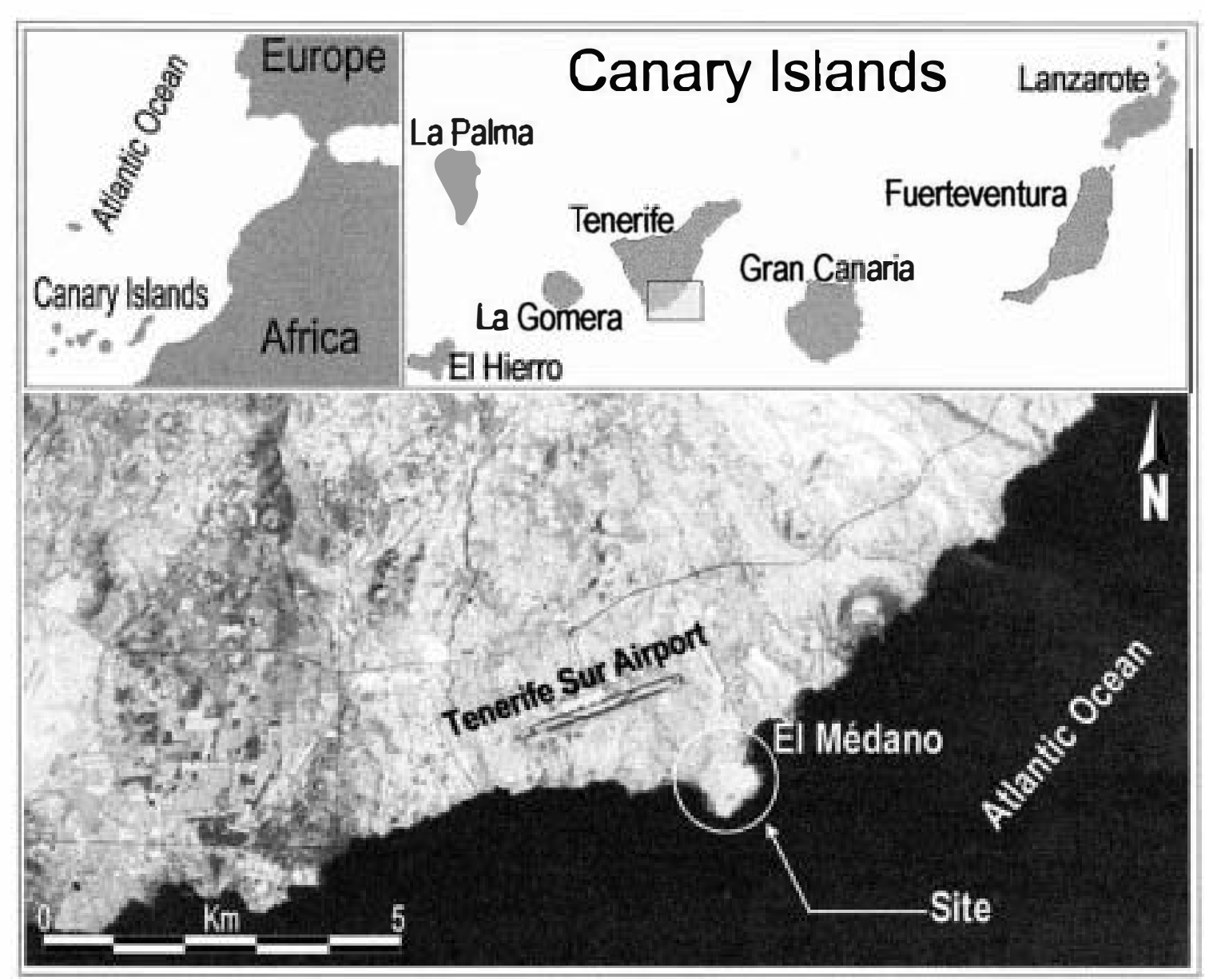

Figure 1. General location of the study area.

This record only reflects earthquakes felt in the most highly populated areas or those asseciated with volcanic eruptions. Knowledge of events occurring on the islands of El Hierrø, La Gomera or the south of Tenerife is practically non existent.

It was not until 1958 that a seismoløgical station was installe in the Canaries. Tw further stations were built in 1975, and over the past few years a more extensive network is being set up, with plans for stations over all the islands (there were seven stations in 202). This will allow greater precision in locating and characterizing earthquakes. The distribution of epicenters recorde over the instrumente peried is shown in Figure 2B.

The largest instrumented earthquake had a moment magnitude $\mathbf{M}=5.2$, its epicenter being in the sea between the islands of Tenerife and Gran Canaria $\left(27^{\circ} 56.8^{\prime} \mathrm{N}\right.$ and $\left.16^{\circ} 12.0 \mathrm{~W}\right)$. Its maximmm intensity was even felt on Tenerife. An analysis of this earthquake (Mezcua et al., 1992) has provided some ideas regarding the seismotectonic setting of the $\mathrm{Ca}$ naries, which could help explain the palecearthquake that cause the paleoliquefaction discussed here. The distribution of aftershocks recorded by a temporary station set up on the south coast of Tenerife between May 9 and June 17, 1989 indicates concentrated aftersh $\bullet \mathrm{ks}$ aløng an $80 \mathrm{~km}$ løng band aligned $\mathrm{N} 33^{\circ}$ (Figure 2C). This earthquake corresponds to a fault of around $30 \mathrm{~km}$ length. The hypecenter depth of the 5.2 magnitude event has been calculate as $50 \mathrm{~km}$ by Mezcua et al. (1992) and as $15 \mathrm{~km}$ by Dziewonski et al. (1990).

The analysis of the focal mechanism and that of the aftershocks points to a NNE-SSW alignment and inclination close to the vertical for the fault. This fault could als have been responsible for seismicity -f greater magnitude and not related to processes of volcanic activity. Further more, geophysical marine 


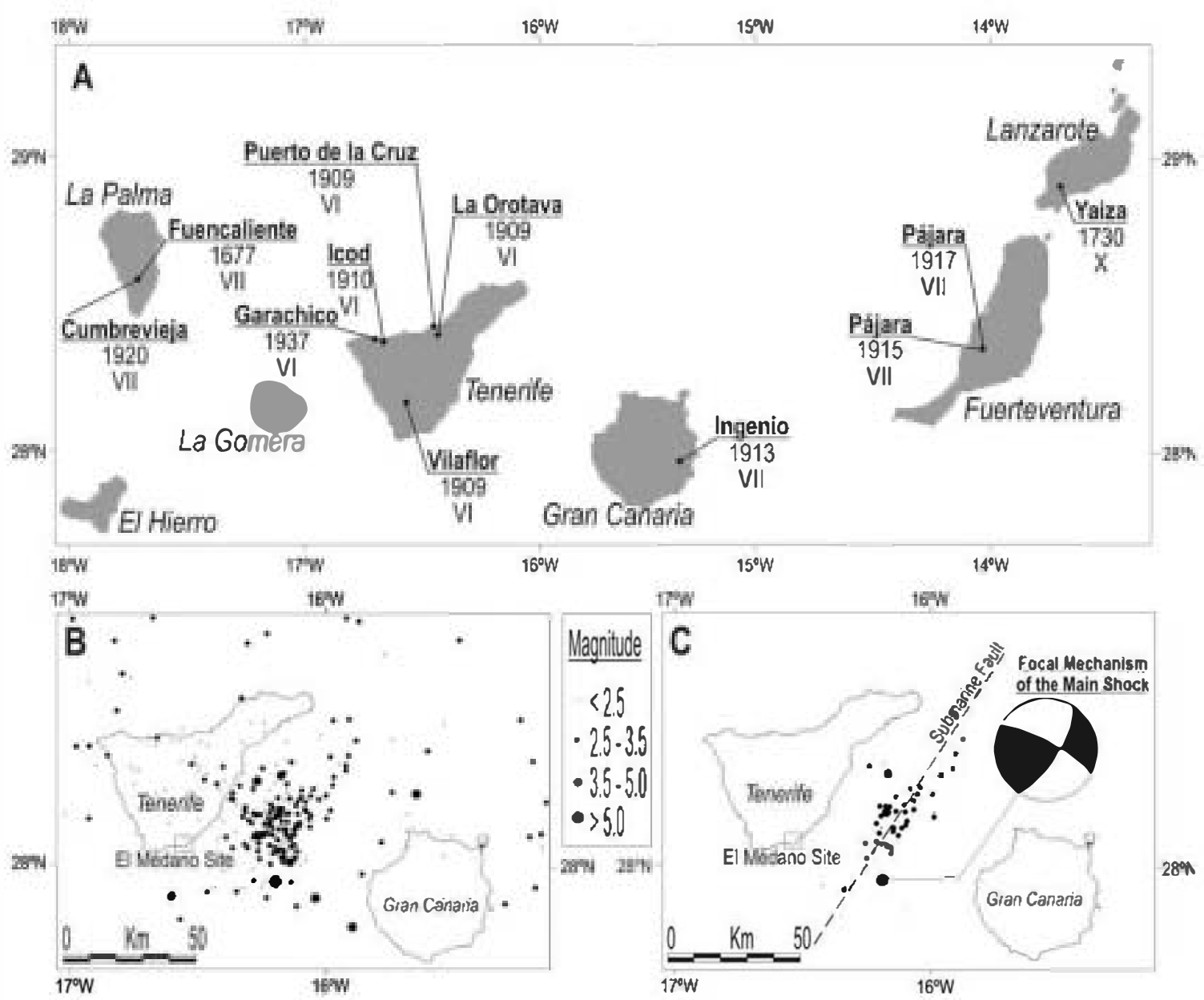

Figure 2. Se ismicity of the Canary Islands. A: Historical se ismicity until 1975 for eatthquakes of inte nsity I $\geq$ VI. B: Earthquale epicenters

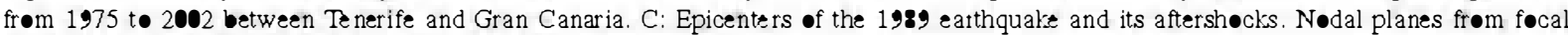
me chanism: $A=33^{\bullet}-71^{\bullet} \mathrm{SE} ; \mathbf{B}=2 \mathbf{9}^{\bullet}-77^{\bullet} \mathrm{NE}$

investigations have tevealed the eccurrence of significant tectønic events (Llanes et al., this vølume) asseciated with epicenters in the sea.

There is an obvious need for investigations that føcus $\bullet$ paleoseismicity and neotectonics in regions for which earthquake information is scarce. This is definitely the case for the Canary Islands, whose instrumental peried is shorter than 30 years and historical record is incomplete.

\section{Geology of the Study Area}

The area investigated is found in El Médan• close t• Leøcadi• Machad• Beach (Figure 3). This beach is bounded inshore by a $40-50$ meter wide range of coastal dunes orientated in a NE-SW directiøn. S॰me small lagøons have formed between the dunes and a coastal platform. This platform overlies a formation of vølcanic tuffs of acid corrp $\bullet$ sition, and descends from the volcanic central part of the island. Towards

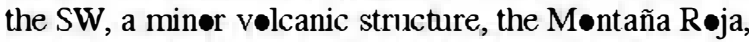
is corrposed of pyr aclastic basaltic materials that $\bullet$ verlie the tuff formation. These materials are overlain by a formation comprising beach sands that rises 2 to $15 \mathrm{~m}$ above sea level and shows several liquefaction structures.

The tuffs correspønd to a set of pyroclastic units related to a phase of explosive salic eruptions between $\bullet .7$ and $0.13 \mathrm{Ma}$. The material is corrposed of pumice lapilli, lithic fagments and sanidine crys-

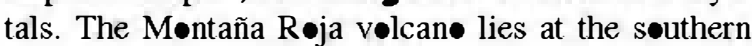
margin of the study area (Figure 3). The volcan॰ is a breached cone, $\bullet$ pen towards the ESE. Its altitude 

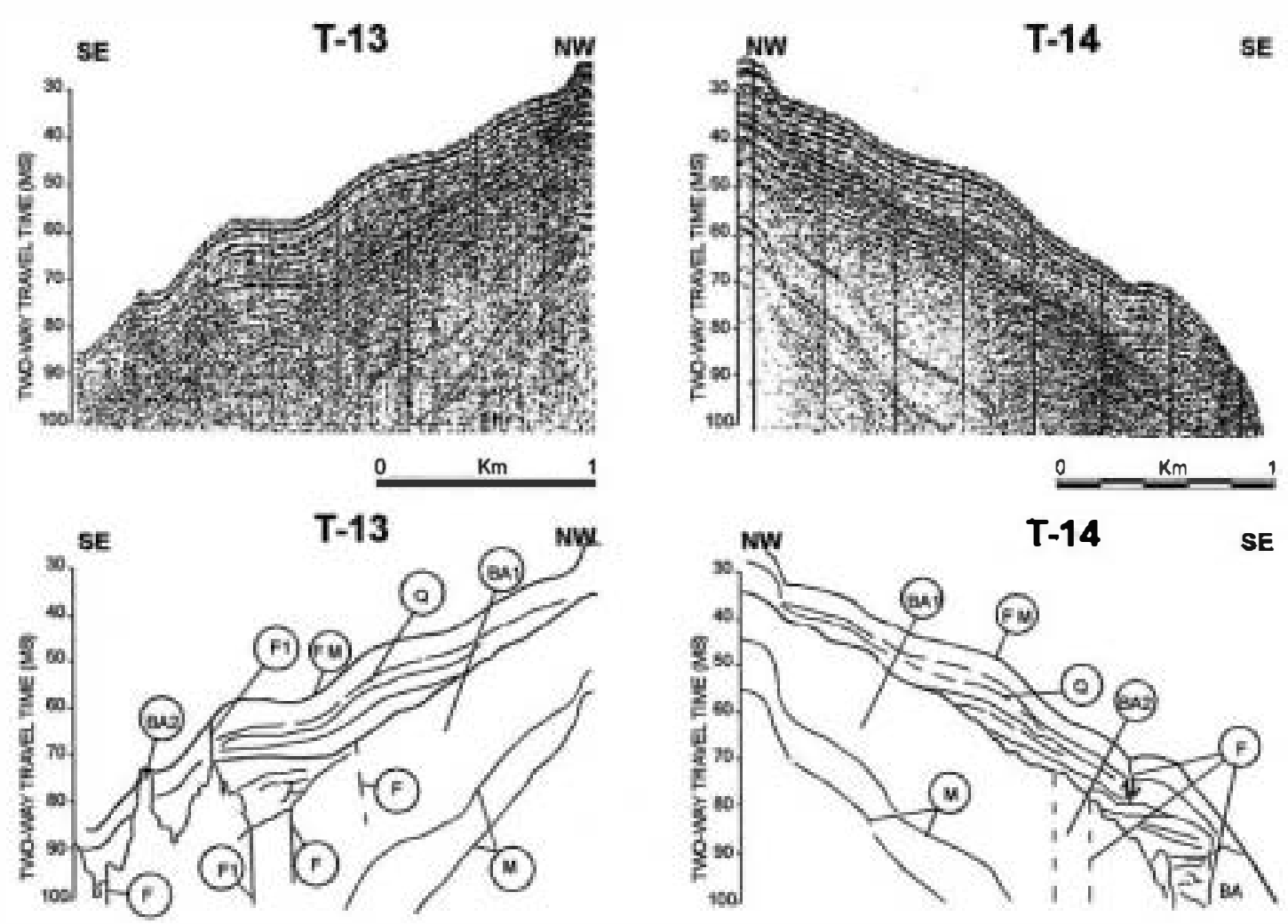

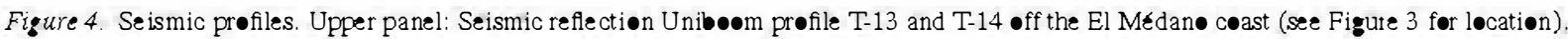
Lower panel: Interpretation drawing: FM: Sea fløor. Quaternary sediments; BA 1: A coustic asement type 2; F1: Fault F1; F: other fractures; M: Multiple

F1 (Figure 4). The minimum length of this fault is $5 \mathrm{~km}$.

The northern fault, F2 (Figure 3), is marked by a less pronounced morphølogical scarp. This fault is best observed at the NE extreme of the mapped area and fades out until it disappears at the SW end. The fault is marked by a slight flexure that preduces a scarp -.5 mhigh with more erosion of the føotwall. A vertical displacement of 0.7 to $1.2 \mathrm{~m}$ has been observed in fault F1. The time of the displacements was after formation of the beach, dated as Holecene as described below.

A set of highly continuous fractures interpreted as jøints mainly affects the tuff formation. Some of these joints, nevertheless, show an intensely curved trace. Although relatively small in number for the area, their inclinations were always close to $\mathbf{9 0}^{\circ}$ vertical. The most common alignments define three sets -f jøints whose directions in order of highest t• løwest frequency are $\mathrm{N} 75^{\circ}, \mathrm{N} 56^{\circ}$ and $\mathrm{N} 105^{\circ}$ (Figure 5).

\section{Description of the liquefaction features}

Liquefaction structures were observed in the uplifted beach sand formation (Figures 3 and 6). This formation extends •ver an area of around $90,000 \mathrm{~m}^{2}$, but could have teach $650, \mathbf{\omega 0} \mathrm{m}^{2}$ in the past 50 years. Changes preduced in coastal dynamics and anthropogenic effects have substantially medified the zone over the last decades, with the almost complete disappearance of the dunes and acceleration of erosive processes. Artificial removal of a large proportion of the uplifted beach sands has led to the current appearance of the study area.

The section observed in the site was as follows frøm top to bottom:

- An upper layer H1 lecated at the top of the deposit composed of coarse to intermediate, highly compact, partially-cemented sands. Its thickness is approximately $1 \mathrm{~m}$. The surface is intensely ereded and shows wind erosion structures indicating its 
A. Joints Strike Direction

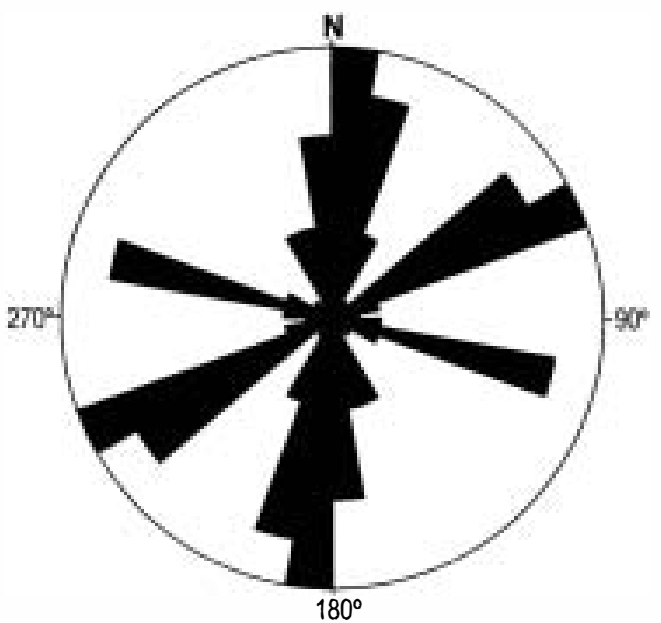

B. Dikes Strike Direction

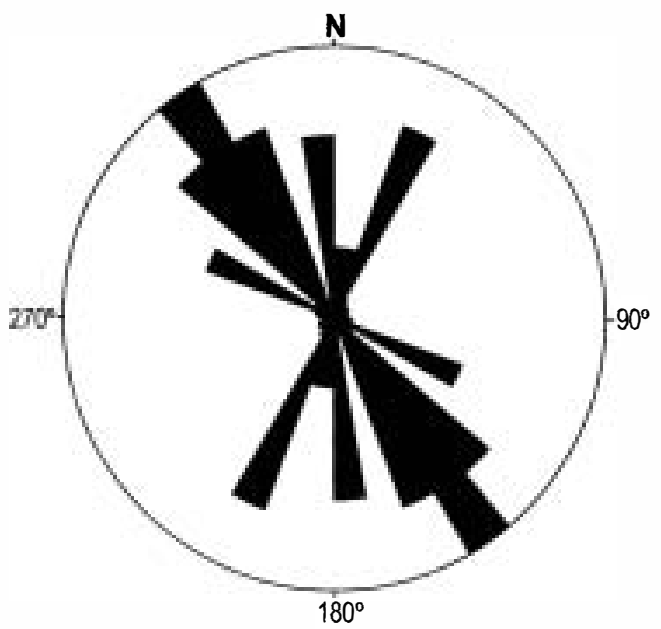

Figure 5. Rose diagrams displaying the two dimensional orientation distribution of data in the form of a circular histogram. A: Joint strike direction; B: Dike strike direction.

thickness was greater, possibly attaining at least $2 \mathrm{~m}$. This layer shows evidence of liquefaction structures, sand dikes and vents described below. Above this layer, small calcareous crusts of $1-10 \mathrm{~cm}$ thickness and altered tuffs appear.

- The lower layer H2, beneath the previous layer, is comprised of medium to coarse sands, somewhat finer and less compact than in layer H1. It shows lamination and cross-stratification. This layer is partially crossed by vents but no dikes are observed. Its thickness ranges from 0.5 to $1 \mathrm{~m}$.

- The substrate is composed of two layers of tuffs, $\mathrm{T} 1$ at the top and T2 at bottom. T1 comprises reddish tuffs weathered to form a $0.5 \mathrm{~m}$ thick paleosol. T2 is formed by yellowish, massive, highly compact pumice tuffs.

Within layers $\mathrm{H} 1$ and $\mathrm{H} 2$ there are numerous liquefaction structures formed by vents and clastic dikes or tabular structures (Figures 7 and 8). These outcrop both at the surface or in natural exposures. The dikes are composed of sands of the same composition as in layer $\mathrm{H} 2$, with strikes of $145^{\circ}, 25^{\circ}, 5^{\circ}$ and $110^{\circ}$ (Figure 5). The $145^{\circ}$ striking dikes, besides being the most frequent, lie almost perpendicular to the direction of the topographical slope, while those trending $110^{\circ}$ show similar directions to the $105^{\circ}$ striking joints. In the mapped area, the length of the dikes reaches 25 $30 \mathrm{~m}$, although they are not easy to observe because of the intense erosion and dune deposits that partly cover them. Dikes are commonly 4 to $8 \mathrm{~cm}$ thick, although in some cases, thicknesses of up to $20 \mathrm{~cm}$ have been measured. Many of these dikes have a central opening or double rim 0.5 to $1.0 \mathrm{~cm}$ wide (Figure 9). The main system $\left(145^{\circ}\right)$ is the most continuous and presents the greatest thicknesses. The dikes show lateral terminations in the shape of thin filaments up to $1 \mathrm{~cm}$ long. Sometimes they cut into each other and also cut the tubular structures.

The formation mechanism of the clastic dikes seems to be related to lateral spreading and hydraulic fracturing mechanisms (Obermeier, 1990). The orientation of the main system $\left(145^{\circ}\right)$ perpendicular to the slope and its greatest thickness and continuity in relation to the other systems could be explained by a mechanism of lateral spreading. Lateral spreading reflects translational movement downslope and separation between individual blocks where shaking has been especially strong (Obermeier et al., 1993). Movement occurs where there is only minor resistance to lateral translation of the cap sitting on liquefied sediment. Besides lateral spreading, the geometry of the dikes ( $145^{\circ}$ and other directions), their orientation, injected material, apical terminations and central apertures all point to a hydraulic fracturing mechanism.

The sand formation also shows numerous tubular structures in the shape of vents with diameters of 8 to $20 \mathrm{~cm}$, whose greatest density coincides with a zone close and parallel to the scarp that marks the surface evidence for fault F1 (Figure 3). These tubes have a very compact peripheral ring with secondary infilling materials of loose sand inside them. Owing to the greater compactness of the ring, erosion has preserved the structures and these may be seen in the outcrops. These structures are present from the lower layer $\mathrm{H} 2$ upwards and cross the upper layer H1 (Figure 7). In 


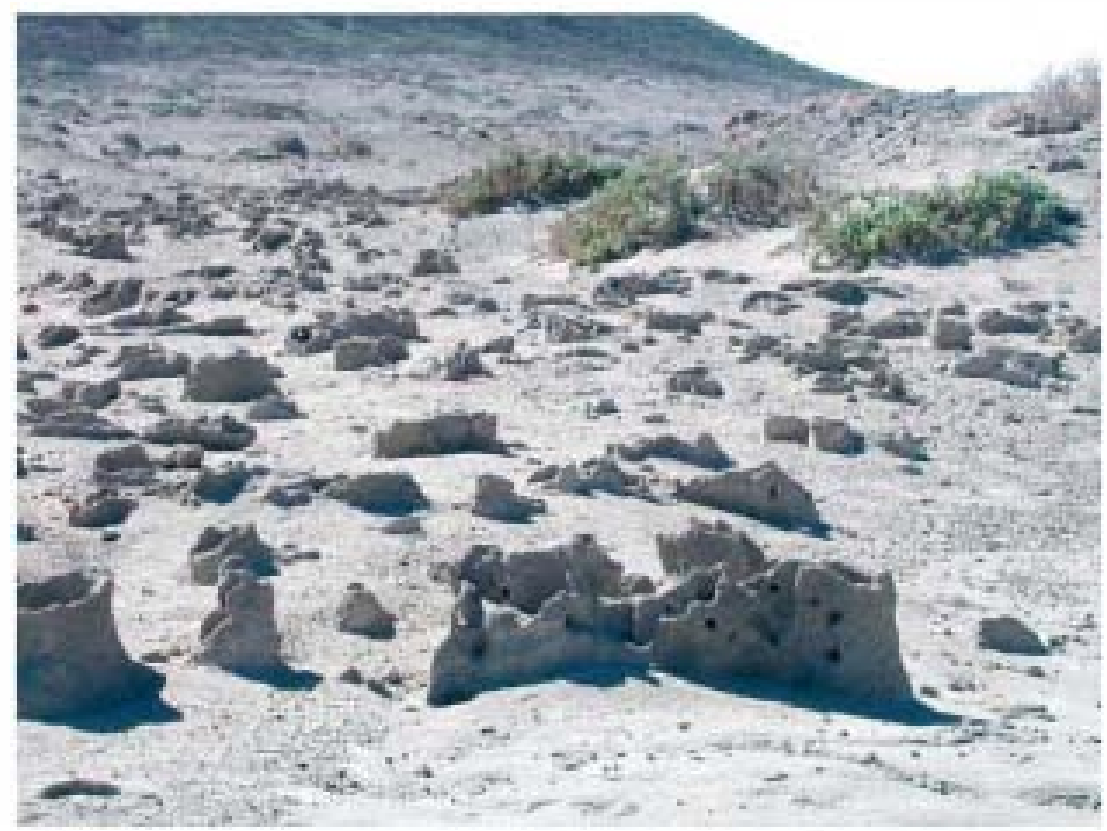

Figure 6 General view of the se ismites zone showing an abundanee of tubular vents. For scale putposes the he ight of the pale ase ismic features is between 20 and $30 \mathrm{~cm}$.

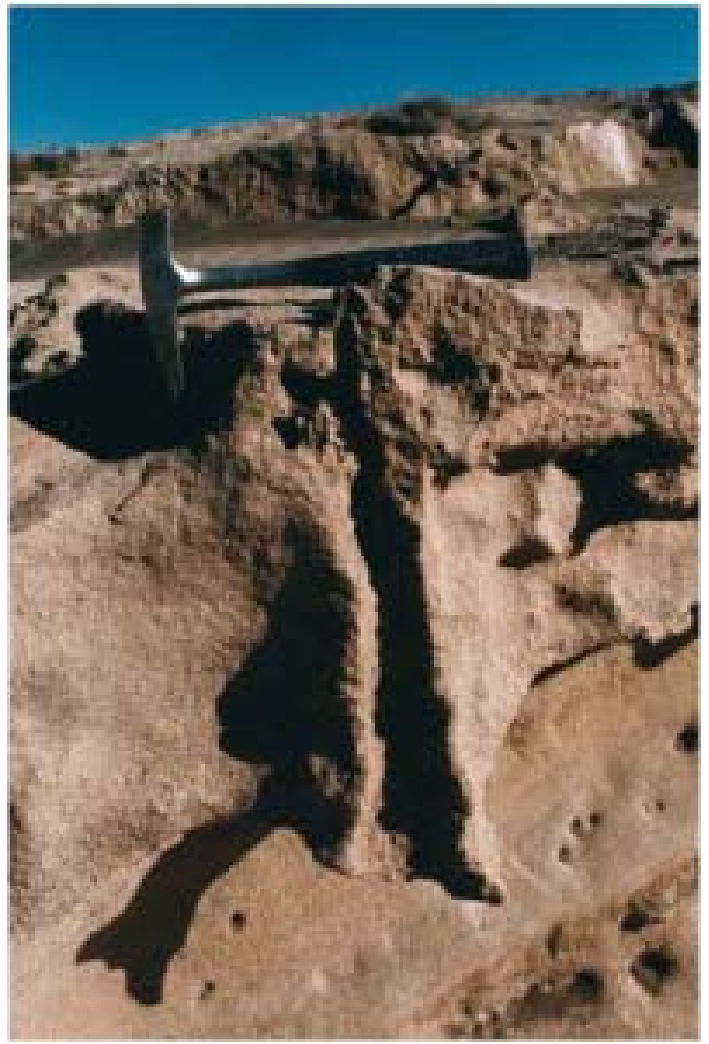

Figure 7 . Longitudinal section of a tubular vent affecting layers $\mathrm{H} 1$ and $\mathrm{H} 2$. For scale purposes the hammer is $30 \mathrm{~cm}$ løn

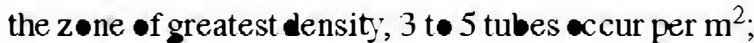
the average being around 2 tubes per $\mathrm{m}^{2}$.

\section{Origin of the liquefaction features}

T• establish the origin of the liquefaction structures, possible causes of both seismic and aseismic nature were analyzed. The following causes were considered:

Volcanic activity. This can generate structures that give rise to vents or tubular conduits, injection of materials, fractures, infills, alteratiøns, etc., as a consequence of the ejection of fluids, gases and materials. The last volcanic episode registered in the area took place $\bullet$ ver 100,000 years age, while the age of the beach deposits is of the order of $10, \mathbf{\omega 0}$ years. The dikes and vents $\bullet$ nly affect the paleobeach deposit and not the tuffs of the substrate, ruling out a possible direct volcanic origin, althøugh hydrothermal processes are being investigated, as a potential secondary process related to the tubular vents.

Biølogical origin. Søme marine and coastal organisms can preduce channels and orifices in beach deposits. However, the size, geometry and arrangement of the structures analyzed preclude this possibility (Calv•, pers. comm., 2002).

Pressure waves and tsunamis. Tsunamis produced by large $\bullet$ ffshore displacements of the sea bottom 
rapidly or almost instantly. The formation of dikes with the injection of sands fransported from a source area by high-energy upward directed hydraulic forces, the apertures or double rims in the dikes and their apical terminations indicate mechanisms of hydraulic fracturing at high pressures. The geological evidence shows that virtually all the dikes must have a seismic liquefaction origin, and could almost certainly have formed solely in response to hydraulic fracturing (Obermeier, 1996). The direction of the tabular dikes is not random as would be expected if the dikes had originated by non-seismic mechanisms. The granulometric characteristics of the sand layers and their high uniformity, geological age and origin, geomorphological conditions and depth of the water table (discussed below), along with the resistance of the sands in which the structures developed are indicative of a high susceptibility of the deposits to liquefaction.

On the basis of the above evidence we can rule out a possible non-seismic origin and propose a seismic origin. This idea is also consistent with the seismotectonic characteristics of the region and the proximity of the previously described faults. The principal mechanism giving rise to the stuctures analyzed, also known as seismites, was liquefaction of the lower layer $\mathrm{H} 2$ that was composed of saturated sands. Due to the effect of intense interstitial pressures, water and sand were transported and expelled towards the surface via the vents, forming sand blows or craters by sand explosion. Hydraulic fracturing or lateral spreading led to rupture of the upper layer $\mathrm{H} 1$ of compact sands, giving rise to sand dike injection. The possibility of more than one earthquake occurring in the zone should not be precluded because of the presence of dikes cutting the vents, possibly implying more than one phase of liquefaction.

The beach sands formation has been dated by thermoluminescence as Holocene (Millán et al., 2002 as $10,081 \pm 933$ years BP). The calcareous crusts that cover some of the liquefaction structures have been dated by the same technique at $3490 \pm 473$ years BP. According to these data, liquefaction and the seismic phenomenon that produce it took place prior to 3490 years ago but after $10 \mathrm{ka}$.

\section{Estimates of acceleration and magnitude of the paleoearthquake}

The force of a seismic event and the magnitude of a paleoearthquake can be estimated by several methods.
These have been reviewe in detail by Obermeier et al. (2001). The following methods are applicable to the present case:

(a) The cyclic stress method based on estimates of the lower-bound peak ground acceleration at individual sites of liquefaction.

(b) The Isihara method, which uses dike height at the site of hydraulic fracturing to estimate the actual value of peak ground acceleration at the site.

(c) The magnitude bound method, which uses the furthest distance from the seismic source to the liquefaction zone.

(d) Energy based solutions.

Methods (a) and (b) serve to calculate the peak acceleration needed for liquefaction to start at a particular site. The cyclic stress method is based on the method of Seed and Idriss (1971) and subsequent updates by Seed et al. (1985) and Youd and Noble (1997). Its application requires the interpretation of the soil profile at the time of liquefaction. To this end, we took into account the current conditions of the sand deposit and the aging processes to which the soil has been subjected from the time of liquefaction to the present.

The most common aging processes are (Olson et al., 2001): destruction of pre-earthquake soil structure and aging effects during liquefaction; post-liquefaction consolidation and densification, and post-liquefaction aging. The main outcome of liquefaction is increased granular packing, which may compact the sediment by some 27\% (Owen, 1987). Following deposition, natural and man-made deposits develop a structure resulting from post-depositional mechanical readjustment and possible weak chemical bonding at particle contacts. This process is referred to as aging. The development of soil structure results in the improvement of soil properties such as shear strength, modulus, and penetration resistance (Schemertmarm, 1991).

The present uplifted sand beach deposits show evidence of these aging processes. The main factors that have contributed to the compaction and partial cementation of the upper $\mathrm{Hl}$ layer are the uplift of the deposits by tectonics and the resultant downdropping of the water table, the geochemical conditions of the environment that favored an input of calcium carbonates and aluminum silicate compounds, and the extremely arid climatic conditions. Sands that could reflect conditions predating the aging processes were identified. These sands occur in the vicinity of the site closest to the coast and show the typical site granulomery and composition. Prior to liquefaction, the soil profile may have been as follows: 
- An upper layer H1 formed of coarse to medium sands, dense to very dense with less than $2 \%$ fines, apparent natural density $1.7 \mathrm{~g} / \mathrm{cm}^{3}$ and $\mathrm{N}_{\mathrm{SPT}}$ (number of blows of the standard penetration test or SPT, ASTM - D1586) equal to or more than 30 blows. Estimated mean layer thickness was $2 \mathrm{~m}$. The water table would have lain towards the base of this layer, and would have been subjected to variations in the water table. Its behavior could correspond to that of a hard, semi-confining and nonliquefiable layer.

- A lower layer H2, comprising medium to coarse sands, relative density intermediate, containing less than $2 \%$ highly uniform fines, apparent natural density $1.5 \mathrm{~g} / \mathrm{cm}^{3}$ and $\mathrm{N}_{\mathrm{SPT}}$ between 15 to 20 blows. The water table would lie above this layer and it would therefore be saturated. Mean estimated layer thickness is $1 \mathrm{~m}$. This layer would have acted as a source zone for liquefaction.

- Layer T1 containing red tuffs weathere to $0.5 \mathrm{~m}$ thick paleosols.

- Layer T2, substrate composed of massive, very compact tuffs.

The cyclic stress method was applied following these hypotheses to estimate the peak ground acceleration (pga) necessary for the soil to undergo liquefaction. The results obtained give an acceleration of $0.22 \mathrm{~g}$ for $\left(\mathrm{N}_{1}\right)_{6 \bullet}=15$ and $0.30 \mathrm{~g}$ for $\left(\mathrm{N}_{1}\right)_{6 \bullet}=$ 20. According to Youd and Noble (1997), this would correspond to a $50 \%$ probability of liquefaction.

The Ishihara (1985) method considers that the maximum height of liquefaction dikes is controlled by two factors: the thickness of the liquefied sediment and the pga. This method is valid for seismic structures produce by hydraulic fracturing. It is applicable where the cap thickness is reasonably uniform and when source sands range from very loose to moderately compact, at least for earthquakes of moment magnitude $\mathbf{M} \sim 7.5$ or larger, (Obermeier, 1998). It was considered that the hard, semi-confining, nonliquefiable layer was $2 \mathrm{~m}$ in thickness and a thickness of $1 \mathrm{~m}$ was assumed for the liquefiable source. For

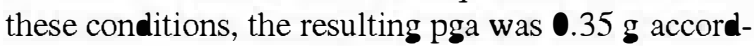
ing to the Ishihara method. Bearing in mind that the cyclic stress method represents the minimum acceleration value, and Ishihara method considers average conditions, a representative value of $0.30 \mathrm{~g}$ was selected from the possible range between 0.22 and $0.35 \mathrm{~g}$.

From the accelerations calculated, intensities at the site can be estimated using one of the avail- able empirical expressions. The equation used in the Spanish Seismic Code is: $I=[3.2233+$ $\left.\log _{10}(\mathrm{a} / \mathrm{g})\right] / \mathbf{0 . 3 0 1 0 3}$, where I are intensities, a is the horizontal pga $\left(\mathrm{cm} / \mathrm{s}^{2}\right)$ and $\mathrm{g}$ is in \% gravity. Hence an acceleration of $13 \mathrm{~g}$ gives a predicted intensity of $\mathrm{XX}$.

The magnitude of paleoearthquakes, in terms of the moment magnitude $\mathrm{M}$, can be calculated using the magnitude bound method and energy based approaches. The magnitude bound method estimates the magnitude of a paleoearthquake using relations between earthquake magnitude and the distance from the tectonic source to the farthest site of liquefaction. It is based on worldwide historical earthquakes (Ambraseys, 1988) and the data described by Obermeier et al. (1993) and Pond (1996). This method requires the identification of the seismic source. In the present case, the closest seismic sources are found between Tenerife and Gran Canaria over a line of epicenters in the ocean, at an approximate distance of $35 \mathrm{~km}$ from the El Médano site (Figure 2C). This source is associated with a NE-SW rending fault that runs parallel to the eastern coast of Tenerife, and was inferred from gravimetric data by Bossard and McFarlane (1970). In 1989, this fault produce the greatest earthquake instrumentally recorded on the archipelago $(\mathbf{M}=5.2)$. The length attributed to this fault is $30 \mathrm{~km}$ (Mezcua et al., 1992), yet it extends to over $8 \mathrm{~km}$. A further possible seismic source is fault F1 located at the site. Its prolongation beneath the ocean was established by reflection seismic profiles indicating a minimum length of $5 \mathrm{~km}$. However, the instrument record makes no reference to earthquakes with epicenters close to this fault, so that we only consider the submarine fault $35 \mathrm{~km}$ from the site as a seismic source when calculating the earthquake's magnitude, which yielded a magnitude $\mathbf{M}$ in the range 6.4 to 6.8 . Given that 6.4 is the lower limit of the data considered by Ambraseys (1988), we took a $\mathbf{M}=6.8$ as being representative. Wells and Coppersmith's (1994) relationship between fault length and magnitude also gives a $\mathbf{M}=6.8$.

The second method use to estimate magnitude is based on so-called energy-based approaches that relate magnitude to energy release (Davis and Berrill, 1982) and subsequent reviews by Berrill and Davis (1985) and Trufinac (1995). This method relates magnitude to distance from the epicenter, to the liquefaction site and the $\left(\mathrm{N}_{1}\right)_{60}$ (number of blows of the SPT for a pressure of $10 \mathrm{t} / \mathrm{m}^{2}$ and an effective energy of $60 \%$ ). For $\left(\mathrm{N}_{1}\right)_{60}=2 \mathbf{0}$, the results obtained indicate a magnitude $\mathbf{M}=6.8$ according to the method of Berrill and 
Davis (1985) and of 7.2 according to that of Trufinac (1995).

In summary, the magnitudes estimated are in the range 6.4 to 7.2; a value of $\mathbf{M}=6.8$ being considered the most representative. These estimates were based on the assumption that the seismic source was the submarine fault. If fault $\mathrm{Fl}$ as being closer to the site was the source of seismicity then models predict lower magnitudes but similar accelerations.

\section{Conclusions}

Several liquefaction structures were identified in El Médano, in southern Tenerife.These structures were clastic dikes and tubular vents; their origin being attributed to the liquefaction of sands by an earthquake of great intensity.

The mechanisms that gave rise to the clastic dikes were hydraulic fracturing and lateral spreading of a layer of compact sands in response to high pore pressures of seismic origin. These pressures, in turn, led to the movement and injection of sands across the compact sands level. The vents are the result of high upward hydraulic pressures causing the ejection of water and sand through these conduits to the surface, possibly forming sand blows and explosion craters.

The peak ground acceleration needed to produce liquefaction and the sand dikes was estimate at $\mathbf{0 . 2 2}$ to $0.35 \mathrm{~g}$. An acceleration of $0.30 \mathrm{~g}$, considered to be the most characteristic, would correspond to an intensity of IX at the site of liquefaction. The magnitude of the earthquake causing liquefaction was calculated to be in the range 6.4 to 7.2 with a value of $\mathbf{M}=$ 6.8 taken to be representative. This result was obtained assuming that a submarine fault was the seismic source.

The liquefaction structures developed over a tectonically uplifted beach of sand deposits dated as $1 \mathbf{0 , 0 8 1} \pm 933$ years BP. Over these sands and liquefaction stuctures, fine calcareous crust levels dated as $3490 \pm 473$ years BP were observed. The paleoearthquake responsible for liquefaction occurred during the Holocene; its age lying between these two dates. Nevertheless, tectonic and geomorphological data from field observations suggest an age closer to the younger constraint.

Two faults F1 and F2 aligned in a direction N55 close to the liquefaction site were identified. Fault F1 cuts the uplifted beach sand formation. Through seismic reflection profiles, its extension under the sea was identified, and a minimum length of $5 \mathrm{~km}$ was established. Both faults limit a small graben, which gives rise to a depression in whose approximate center there are several lagoons.

Possible seismic sources near the site of liquefaction were considered. The main source is inferred to have been a submarine NNE-SSW trending fault some $35 \mathrm{~km}$ from the site between the islands of Tenerife and Gran Canaria. Its movement takes the form of a sinistral thrust. This fault shows associated seismicity. Another proposed source is fault Fl, which affects the sand formation where the paleoliquefaction is found. No historical epicenters related to this fault have been recorded.

The tectonic structures affecting materials of recent age and the seismicity associated with these structures demonstrates existing seismotectonic relationships and confirms the paleoseismic activity identified in southern Tenerife. The paleoearthquake investigated here is the largest of those registered on the Canary Islands.

The presence of active faults affecting materials of very recent age and their association with a paleoearthquake of high intensity in the south of Tenerife are key factors that need to be borne in mind when evaluating seismic hazards on the Canaries, a region, which up until now, had been considered to be of low seismic activity.

\section{Acknowledgements}

We are grateful to Dr. A. Millán of the Universidad Autónoma de Madrid for carrying out the thermoluminescence procedures. Dr. S. Obermeier from the US Geological Survey (Emeritus), Professor F. Ricci Lucchi of the Universita di Bologna and Professor J. P. Calvo of the University Complutense of Madrid are thanked for their helpful comments and advice. Thanks are also due to Dr. M. A. Rodriguez Pascua and P. Llanes for providing useful information. Finally, we are grateful for the efforts of reviewers whose comments have helped improved the manuscript.

\section{References}

\footnotetext{
Ambraseys, N. N. 1988. Engineering seismøløgy. Earthq. Eng. Struct., D., 17(1), 1-105.

Berril, J. B. and Davis, R. O. 1985. Energy dissipation and seismic liquefaction of sands revised model. Soils and Found., 25(2), $106-118$.
} 
Bosshard, E. and MacFarlane, D. J. 1970. Crustal structure of the westerm Canary Islands fron seismic refraction and gravity data J. Geophys. Res., 75, 4901-4918.

Davis, R. O. and Berril, J. B. 1982 Energy dissipation and seismic liquefaction of sands. Earthq. Eng. Struct. D., 10, 59-68.

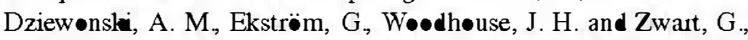

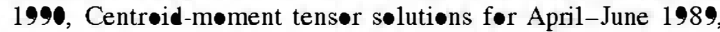
Phys. Earth Planet. Int. 60, 243-253.

Ishihara, K. 1985. Stability of material dep•sit during earthquakes. Proc. 11 th. Int. Conf.Soil. Mech. and Found. Eng. San Francisce, Vø1 I. 321-376. A. A. Balkema, Røtterdam.

Llanes, P., Muñøz, A. Muñøz-Martín, A., Acøsta, J., Herranz, P.,

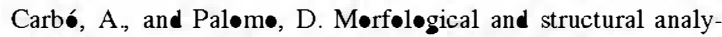
sis in the Anaga offshore massif, Canary Islands: fractures and debris avalanches relationships. Mar. Geophys. Res., (in this v•lume)

Mezcua, J, Burforn, E., Udías, A. and Rueda, J, 1992. Seismotectønic of the Canary Islands. Tectonophysics, 208, 447-452.

Millan, A., Benitez, P. and Calderón, T. 2002. Datación absøluta p•r termøluminiscencia de muestras de paleøplayas de Tenerife. Lab. Datación y Radiøquímica. Universidad Autón $\bullet$ ma de Madrid. España. (Unpublish).

Obermeier, S. F. 1996. Use of liquefaction -induced features før paleosismic analysis. Eng. Geol., 44, 1-76.

Obermeier, S. F. 1998. Overview $\bullet$ liquefactiøn evidence før strøng earthquakes of Høløcene and latest Pleistøcene ages in the states -f Indiana and lin॰is, USA. Eng. Geol., 50, 227-254.

Obermeier, S. F., Martin, J. R., Frankel, T. L., Munsøn, P. J., Mun-

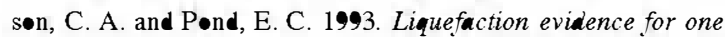
or more strong Holocene earthquakes in the Wabash Valley of southerm Indiana and Illinois. U.S. Geol. Survey Prof. Paper, 1536, 27 pp.
Obermeier, S. F., Pønd, E. C. and Olsøn, S. C. 2001. Paleoliquefaction studies in continental settings: geological and geotecnical features in interpretations and back-analysis. U.S. Geol. Survey. -penjile Report, 01-29. 75 pp.

Olsøn, S. M., Obermeier, S. F. and Stark, T. D. 2001. Interpretatiøn of penetration resistence for back analysis at sites of previøus liquefaction. Seism. Res. Lett., 72(1), 46-59.

Owen, H. G. 1987. Deformation processes in unconsolideted sands. In: Deformation of Sediments and Sedimentary Rocks. Jønes,

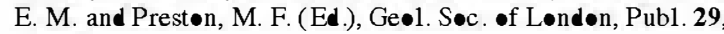
11-24.

P॰nd, E. C. 1996. Seismic parameters for the central United States based on paleoliquefaction evidence in the Wabash Valley. $\mathrm{Ph} \mathrm{D}$ Thesis. Virginia P•lytech. Inst. Blacksburg, Virginia, 583 pp

Schemertmann, J. H. 1991. The mechanical aging of søils. J. Geotech. Eng-ASCE, 117(1), 1288-1330

Seed, H. B. and Idriss, I. M. 1971. Simplified procedure før evaluating søil liquefaction pøtential. J. Soil Mech. Found. Div. ASCE 97(1), 1249-1273.

Seed, H. B., Tølimatsu, K., Harder, L. F. and Chung, R. M 1985. Influence of SPT procedures in søil liquefaction resistence evaluations. J. Soil Mech. Found. Div. ASCE, 111, 1425-1445.

Trifunac, M. D. 1995. Empirical criteria for liquefaction in sands via standard penetration test and seismic wave energy. Soil Dyn. Earthq. Eng., 14, 419-426.

Wells, D. L. and Cøppersmith, K. J. 1994. New empirical relationships amøng magnitude, rupture length, rupture area, and surface dispklacement. B. Seismol. Soc. Am., 84, 974-1002.

Yøud, T. L. and Nøble, K. 1997. Liquefaction criteria based •n statistical and probabilistic analysis. Proc. NCEER Workshop on Evaluation of Liquefaction Resistence of Soils. Yøu, T. L. and Idriss, I. M. (Eds.), Tech. Rep.NCEER-97-0022, State University

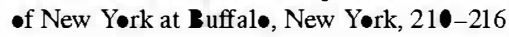

